\title{
Cutaneous thermosensitivity differences among the face, hand or thigh appear not to exist for skin blood flow during normothermic states
}

\author{
Catriona A Burdon, Kyoko Tagami, Joonhee Park, Joanne N Caldwell, Nigel AS Taylor \\ From 15th International Conference on Environmental Ergonomics (ICEE XV) \\ Portsmouth, UK. 28 June - 3 July 2015
}

\begin{abstract}
Introduction
Variations in the volume of the sensory cortex (homunculus) assigned to different skin regions may lead one to postulate that thermal stimulation of some body segments (e.g. face, hand) may evoke more powerful autonomic responses. That is, there may exist a mosaic of cutaneous thermosensitivity. To study thermosensitivity, thermal feedback from sites other than the treated site needs to be minimised. This is achieved via whole-body clamping of deep-body and skin temperatures. Previously, greater sensitivity of the face was observed for sudomotor control in mildly hyperthermic individuals [1], so the aim of this investigation was to explore possible sensitivity variations in the control of skin blood flow during isolated stimulation of three sites, but after a normothermic clamp had been established.
\end{abstract}

\section{Methods}

Nine subjects ( 5 males, 4 females) participated in two trials with limb-segment blood flow measured at the hand and forearm, but in separate trials (right side; water-displacement plethysmography). Deep-body (aural) and skin temperatures were clamped at normothermic levels using a whole-body, water-perfusion suit. The three treated skin sites (face, left hand, left thigh) were then stimulated using individual water-perfusion patches of the same surface area, to both elevate and reduce local skin temperature $\sim 5^{\circ} \mathrm{C}$ from baseline temperatures.

\section{Results}

Mean body temperature $\left(36.7^{\circ} \mathrm{C}, \mathrm{SD} 0.2\right)$ for the two trials was not different $(P>0.05)$, verifying successful
Table 1 Change in hand and forearm blood flow during thermal stimulation of the face, hand and thigh.

\begin{tabular}{|c|c|c|}
\hline Treated site & $\begin{array}{l}\text { Hand and forearm } \\
\text { ( } \mathrm{mL} .100 \mathrm{~mL} \text { tissue }\end{array}$ & changes \\
\hline & Heating & Cooling \\
\hline Face & 2.73 (SD 1.65) & -1.54 (SD 1.49) \\
\hline Hand & 3.40 (SD 2.98) & -1.59 (SD 1.00) \\
\hline Thigh & 1.93 (SD 1.81) & -2.17 (SD 2.02) \\
\hline
\end{tabular}

clamping. Local heating $\left(4.9^{\circ} \mathrm{C}\right.$, SD 1.1) increased, while cooling $\left(-5.2^{\circ} \mathrm{C}\right.$, SD 1.2$)$ depressed both hand and forearm blood flows $(P<0.05$ for all comparisons). There were no differences in the size of these responses to either thermal treatment, regardless of the skin site stimulated. Furthermore, whilst hand and forearm blood flows were not identical, their responses were of equivalent magnitude $(P>0.05)$. Therefore, these changes were combined, with the resulting data contained in Table 1.

\section{Discussion}

As expected, thermal stimulation produced significant effector responses. However, as opposed to previous observations, this did not differ among sites when subjects were normothermic. It is therefore concluded that local differences in cutaneous thermosensitivity appear not to exist with respect to skin blood flow modulation in this thermal state, at least for those sites investigated. In an accompanying communication, this question is addressed again, but now with subjects in a mildly hyperthermic state.

Published: 14 September 2015

\footnotetext{
* Correspondence: nigel_taylor@uow.edu.au

Centre for Human and Applied Physiology, School of Medicine, University of Wollongong, Wollongong, Australia
} 


\section{Reference}

1. Cotter JD, Taylor NAS: Distribution of cutaneous sudomotor and alliesthesial thermosensitivity in mildly heat-stressed humans: an openloop approach. Journal of Physiology 2005, 565:335-345.

doi:10.1186/2046-7648-4-S1-A116

Cite this article as: Burdon et al:: Cutaneous thermosensitivity differences among the face, hand or thigh appear not to exist for skin blood flow during normothermic states. Extreme Physiology \& Medicine 2015 4(Suppl 1):A116

Submit your next manuscript to BioMed Central and take full advantage of:

- Convenient online submission

- Thorough peer review

- No space constraints or color figure charges

- Immediate publication on acceptance

- Inclusion in PubMed, CAS, Scopus and Google Scholar

- Research which is freely available for redistribution 